\title{
Eclipse effects on field crops and marine zooplankton: the 29 March 2006 total solar eclipse
}

\author{
G. Economou ${ }^{1}$, E. D. Christou ${ }^{2}$, A. Giannakourou ${ }^{2}$, E. Gerasopoulos ${ }^{3}$, D. Georgopoulos ${ }^{2}$, V. Kotoulas ${ }^{1}$, D. Lyra ${ }^{1}$, \\ N. Tsakalis ${ }^{1}$, M. Tzortziou ${ }^{4,5}$, P. Vahamidis ${ }^{1}$, E. Papathanassiou ${ }^{2}$, and A. Karamanos ${ }^{1}$ \\ ${ }^{1}$ Lab. of Agronomy, Faculty of Plant Production, Agricultural Univ. of Athens, 75 Iera Odos Str., 11855 Athens, Greece \\ ${ }^{2}$ Institute of Oceanography, Hellenic Center for Marine Research, 19013 Anavyssos, Greece \\ ${ }^{3}$ Institute for Environmental Research and Sustainable Development, National Observatory of Athens, Greece \\ ${ }^{4}$ NASA Goddard Space Flight Center, ESSIC/Univ. of Maryland, Smithsonian Institution, SERC, USA \\ ${ }^{5}$ Institute of Inland Waters, Hellenic Center for Marine Research 19013 Anavyssos, Greece
}

Received: 1 October 2007 - Published in Atmos. Chem. Phys. Discuss.: 25 January 2008

Revised: 13 June 2008 - Accepted: 17 June 2008 - Published: 12 August 2008

\begin{abstract}
Some effects in the biosphere from the Total Solar Eclipse of 29 March 2006 were investigated in field crops and marine zooplankton. Taking into account the decisive role of light on plant life and productivity, measurements of photosynthesis and stomatal behaviour were conducted on seven important field-grown cereal and leguminous crops. A drop in photosynthetic rates, by more than a factor of 5 in some cases, was observed, and the minimum values of photosynthetic rates ranged between 3.13 and $10.13 \mu \mathrm{mol} \mathrm{CO} \mathrm{CO}^{-2} \mathrm{~s}^{-1}$. The drop in solar irradiance and the increase in mesophyll $\mathrm{CO}_{2}$-concentration during the eclipse did not induce stomatal closure thus not blocking $\mathrm{CO}_{2}$ uptake by plants. Light effects on the photochemical phase of photosynthesis may be responsible for the observed depression in photosynthetic rates. Field studies addressing the migratory responses of marine zooplankton (microzooplankton (ciliates), and meso-zooplankton) due to the rapid changes in underwater light intensity were also performed. The light intensity attenuation was simulated with the use of accurate underwater radiative transfer modeling techniques. Ciliates, responded to the rapid decrease in light intensity during the eclipse adopting night-time behaviour. From the meso-zooplankton assemblage, various vertical migratory behaviours were adopted by different species.
\end{abstract}

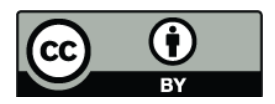

Correspondence to: A. Karamanos (akaram@aua.gr)

\section{Introduction}

On 29 March 2006, millions of people in the Northern Hemisphere had the opportunity to observe a total solar eclipse. In the Greek territory, the phenomenon had a maximum duration of 2 minutes and $58 \mathrm{~s}$, at the small island of Kastelorizo, in the east-southern part of the country. The eclipse effects on the biosphere and on various atmospheric layers have been investigated during a combined field experiment over Greece. Information about the experimental campaigns, the measurement sites, eclipse path maps and eclipse local circumstances at each location, can be found in the overview paper by Gerasopoulos et al. (2007).

The effects of solar eclipses on the behaviour of living organisms have been the subject of many observations in the past. Plant behaviour was first studied by Deen and Bruner (1933), by following stomatal movements of the gray birch during the sun eclipse of 1932. Two Polish zoologists were the first to observe the behaviour of mammals, birds, and insects during seven eclipses between 1954 and 1975 (Zirker, 1995). More recent data have shown that birds behave as they normally do at sunset (Tramer, 2000), animals alter their behaviour (Jennings et al., 1998) and some planktonic crustacea are vertically redistributed (Vecchione et al., 1987; Giroud and Balvay, 1999).

In general, eclipse effects on plants are expected to be related to the light limitation experienced during the phenomenon. Although fluctuating light conditions are a common feature for natural habitats (e.g. through transitional light flecks in canopies, changing cloudiness, diurnal periods of light and dusk) (Schulze and Hall, 1982; Küppers et al., 1997); the sudden drop in solar irradiance during a solar

Published by Copernicus Publications on behalf of the European Geosciences Union. 
eclipse provides a challenge for investigating its related impacts on plant behaviour. Observations have shown that a drop of sap flow velocity in a number of plants was related to solar eclipses (Ladefoged, 1963; Fernandez et al., 1996; Morecroft et al., 2000; Häberle et al., 2001). Developmental processes, such as transient aberrations in the chromosomal structure of root meristems and delayed seed germination, have been also ascribed to the impact of an eclipse (Sathaiah et al., 1984; Kumar et al., 1984). In addition, limited short-term effects on photosynthesis and evapotranspiration of crop plants, such as pigeon pea and bread wheat, were reported by Singh et al. (1992). In mature forest trees of Picea abies, Fagus sylvatica and Quercus robur photosynthesis was reduced to an extent that allowed net $\mathrm{CO}_{2}$ evolution from leaves during an eclipse (Häberle et al., 2001).

Moreover, it is very interesting that this natural experiment takes place under particularly degraded conditions by means of air quality, which pose additional impact on plants. For instance, eastern Mediterranean experiences ozone levels that are year round above the EU phytotoxicity limit of $32 \mathrm{ppb} / 24 \mathrm{~h}$ (Kourtidis et al., 2002; Kouvarakis et al., 2002; Kondratyev and Varotsos, 2002; Gerasopoulos et al., 2005, 2006a), while enhanced particulate matter levels (Gerasopoulos et al., 2003, 2006b) do also influence the fraction of solar irradiance reaching the surface (Zerefos et al., 1998; Papayannis et al., 1998; Varotsos et al., 2001).

The effects of solar eclipses on marine ecosystems have been partially studied. Pepita (1955) reported an upward migration of free-swimming larvae of shrimps, clams, snails and barnacles, as well as of adult copepods during the period of maximum totality, in Sebastopol Bay. Skud (1967) observed a decrease in zooplankton volumes at surface waters in Maine, although he reported an upward migration of two copepod species (Pseudocalanus minutus and Acartia longiremis), during the time of darkness. Adult copepods moved upwards in the water column during an eclipse event observed in the region of Boothbay harbor, Maine, in March 1970 (Sherman and Honey, 1970). Similarly, Bright et al. (1972) found that certain species of copepods and euphausiaceans (e.g. Nannocalanus minor, Scolecithrix danae and Undinula vulgaris) in the Gulf of Mexico, responded to the noontime solar eclipse of March 1970 by migrating to the surface. Moreover, according to Bright et al. (1972), the response as reflected in the number of organisms captured at the surface, was larger than the respective response to a decrease in light intensity at night. Some studies of the movements of scattering layers during solar eclipses showed that layers started ascending at the beginning of the eclipse (Backus et al., 1965; Tont and Wick, 1973; Kampa, 1975), while in other cases the scattering layers did not respond at all (Franceschini et al., 1970).

The diurnal vertical migration of many zooplankters is a well known behavior, with some of the organisms migrating several hundred meters in the water column (Marshall and Orr, 1955; Longhurst, 1976). The factors controlling vertical migration in mesopelagic species, however, have not been intensively studied. It is generally accepted that down-welling irradiance plays an important role (Banse, 1964; Ringelberg, 1995), since most vertical migrations of plancton occur at sunrise and sunset. Although, most of the above studies concern mesozooplankton there is lack of information concerning other zooplankton organisms.

The scope of this study is to investigate some of the effects of the 29 March 2006 total solar eclipse on living organisms of two diverse ecosystems, terrestrial and marine. In the former case, the effects of eclipse on the carbon assimilation of field crops, whereas in the latter the migratory responses of marine zooplankton, will be examined. Evidently, the reaction of the organisms to the unexpected dark spell is expected to vary substantially between the two ecosystems, and there is great difficulty to associate them. Instead, more information concerning the mechanisms involved in the reaction of the organisms within each ecosystem will be extracted. In field crops, the effects of the reduced photon flux density on $\mathrm{CO}_{2}$-uptake will be interpreted through simultaneous observations on stomatal behaviour and other parameters of the assimilatory pathways involved. As regards the migratory responses of marine zooplankton, field studies addressing this issue are scarce, primarily because of the difficulties associated with measuring rapid changes in underwater light intensity, simultaneously with changes in animal distributions. In this study, this has been overcome with the use of accurate underwater radiative transfer modeling.

\section{Materials and methods}

\subsection{Photosynthesis and stomatal conductance in field crops}

\subsubsection{Study site}

The study was carried out at the experimental field of the Agricultural University of Athens $\left(37^{\circ} 59^{\prime} \mathrm{N}, 23^{\circ} 32^{\prime} \mathrm{E}\right)$, at an altitude of $30 \mathrm{~m}$ a.s.l. The site was located about $560 \mathrm{~km}$ from the central axis of the eclipse totality, with $84 \%$ sun obscuration. The crops have been growing in a slightly alkaline $(\mathrm{pH}$ 7.24 ) clay loam soil (35.9\% sand, $35.9 \%$ silt and $29.8 \%$ clay) over an area of $400 \mathrm{~m}^{2}$.

\subsubsection{Plant material}

Seven important field-grown cereal and leguminous crops were studied. In particular, the studied crops were: cereals [Triticum durum (durum wheat), Tr. aestivum (bread wheat), Hordeum vulgare (barley), Avena sativa (oat)] and legumes [Lathyrus sativus (grass pea), Pisum sativum (pea) and Vicia faba (faba bean)]. On 29 March 2006 all cereals were at the booting stage and the legumes at flower appearance. The measurements were taken on the third leaf from the top for the cereals and on the leaves at the middle of the stem for the legumes. 
2.1.3 Measurements of photosynthesis and stomatal conductance

The chlorophyll fluorescence technique was used to measure the photosynthetic activity of leaves. Net photosynthesis $\left(P_{n}\right)$, mesophyll $\mathrm{CO}_{2}$-concentration $\left(C_{i}\right)$ and stomatal conductance $\left(g_{s}\right)$ were measured in the field, using a closed portable Infra-Red Gas Analysis system (IRGA, LICOR, LI-6200 model). Each leaf was enclosed in a 41 chamber connected to the IRGA, and the instrument was moved from crop to crop for consecutive measurements within less than one minute. Air flow rate into the IRGA system was $800 \mu \mathrm{mole} \mathrm{s}^{-1}$. The Photosynthetically Active Radiation (PAR) measured with a quantum sensor connected to the chamber, was also recorded in parallel to $P_{n}$ and $g_{s}$ measurements. $P_{n}$ and $g_{s}$ calculation was based on the equations of Leuning and Sands (1989) and are expressed as $\mu$ mol $\mathrm{CO}_{2} \mathrm{~m}^{-2} \mathrm{~s}^{-1}$ and mole $\mathrm{H}_{2} \mathrm{O} \mathrm{m}^{-2} \mathrm{~s}^{-1}$, respectively. Hourly measurements were carried out from 06:00-17:00 UTC, on 29 March 2006.

Additional meteorological and actinometric data monitored at Thission station (National Observatory of Athens, at a distance of about $2 \mathrm{~km}$ eastern of the experimental site) were used in this study. Information about the station characteristics and infrastructure used can be found in Founda et al. (2007).

\subsection{Marine zooplankton}

\subsubsection{Study site and hydrographic measurements}

One oceanographic cruise on board the R/V AEGAIO was carried out on 29 March 2006, at a fixed station close to Kastelorizo Island in the Eastern Mediterranean $\left(36^{\circ} 08^{\prime} \mathrm{N}\right.$, $\left.29^{\circ} 34^{\prime} \mathrm{E}\right)$. Downward surface global $(200-850 \mathrm{~nm})$ and direct $(280-700 \mathrm{~nm})$ irradiance spectra were measured during 09:00-13:00 UTC at a sampling frequency of $20 \mathrm{~s}$ and $8 \mathrm{~s}$, respectively, using two diode-array spectrometers (Kazadzis et al., 2007; Blumthaler et al., 2006).

The water column structure was sampled before, during, and after the eclipse, at approximately $1 \mathrm{~h}$ intervals, during an $8 \mathrm{~h}$ period (Table 1). Vertical profiles of temperature and salinity were measured with a Seabird CTD System (911 plus) assembly. Phytoplankton fluorescence (Chl- $a$ ) was recorded with a Chelsea in situ fluorometer. Water samples were taken in the euphotic $0-100 \mathrm{~m}$ layer, using Niskin bottles with teflon-coated springs and O-rings. For microzooplankton, 7 replicate samples were taken hourly, at steps of $10 \mathrm{~m}$ in the water column, whereas for mesozooplankton, 6 replicates of samples were collected hourly at discrete layers (0-10 m, 10-20 m, 20-50 m, 50-100 m, 100-200 m).

\subsubsection{Zooplankton measurements}

Five hundred $\mathrm{ml}$ micro-zooplankton samples were preserved with borax-buffered formalin (final concentration $2 \%$
Table 1. Micro-zooplankton and meso-zooplankton samplings before, during and after the total solar eclipse at Kastelorizo marine station (max depth $290 \mathrm{~m}$ ).

\begin{tabular}{cccc}
\hline & & \multicolumn{2}{c}{ Zooplankton Measurements } \\
Cast & Time (UTC) & Micro- & Meso- \\
\hline K1 & $7: 52$ & + & + \\
K2 & $9: 00$ & & + \\
K3 & $9: 40$ & + & + \\
K4 & $10: 20$ & + & + \\
K5 & $11: 20$ & + & + \\
K6 & $12: 50$ & + & + \\
K7 & $14: 15$ & + & + \\
\hline
\end{tabular}

formaldehyde) and stored at $4^{\circ} \mathrm{C}$ in the dark. Before examination, samples were left to settle in their bottles in the dark at $4^{\circ} \mathrm{C}$ and after $48 \mathrm{~h}$, the top $400 \mathrm{ml}$ of the sample was slowly siphoned off. The bottom $100 \mathrm{ml}$ of the sample was transferred into sedimentation chambers, was allowed to settle for $24 \mathrm{~h}$ (Utermohl, 1958) and was finally examined by means of an inverted microscope OLYMPUS IX 70.

Meso-zooplankton was sampled by vertical hauls of a WP2 net $(200 \mu \mathrm{m}$ mesh size). Samples were fixed immediately after collection and preserved in a $4 \%$ borax bufferedformaldehyde seawater solution. In the laboratory the samples were split using a folsom splitter. The first half was used to get information on the taxonomic level of order or species and counted under an OLYMPUS stereoscope.

\subsubsection{Underwater radiative transfer modeling}

Measured changes in above water light intensity and underwater composition during the solar eclipse, were used as input to the extensively validated Hydrolight Radiative Transfer Program (Mobley, 1988), to estimate changes in underwater radiation fields. In the absence of in situ underwater radiometric measurements, the model calculations allowed us to estimate the changes in light levels (e.g. PAR) at specific depths in the water column, where changes in micro- and meso-zooplankton concentrations were observed during the solar eclipse event. Mobley (1994) has given a detailed description of the physical assumptions and mathematical calculations in the Hydrolight Model. Tzortziou et al. (2006) recently reported very good agreement (differences less than $10 \%$ ) between in situ measurements of water leaving radiance and Hydrolight results, over a wide range of conditions in the bio-optically complex estuarine waters of the Chesapeake Bay, and demonstrated very good optical closure between independently measured quantities.

Measurements of downward surface irradiance spectra, $E_{S}(\lambda)$, and chl- $a$ vertical profiles were used as inputs to perform the model calculations. The water was modeled by three components: pure water, pigmented particles and covarying colored dissolved organic matter (CDOM). We 

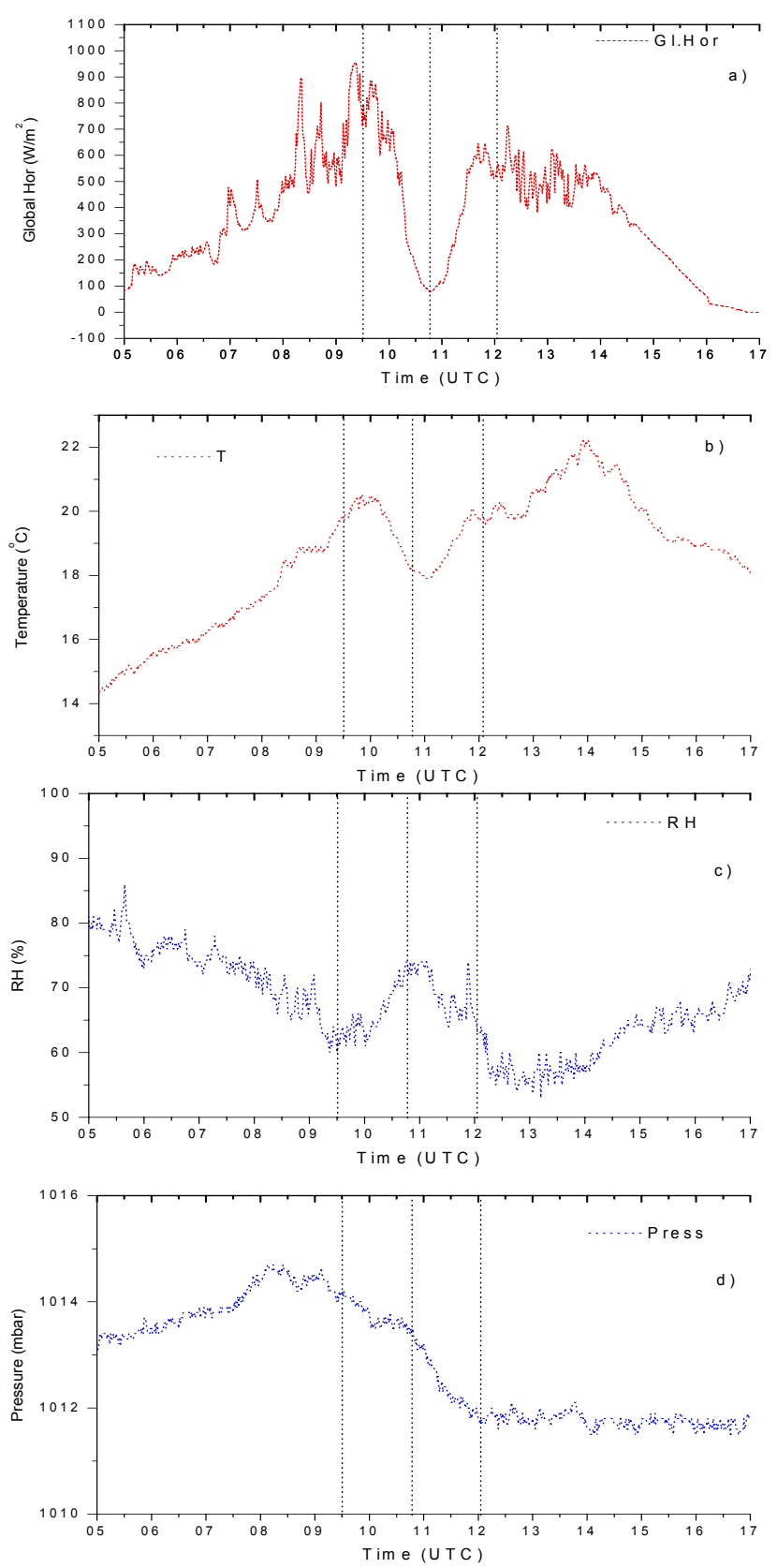

Fig. 1. The diurnal course of meteorological parameters (a) Global Horizontal Irradiance, (b) Temperature, (c) Relative Humidity and (d) Pressure, during 29 March 2006, at Thission station, Athens (National Observatory of Athens).

assumed that mineral concentrations were negligible in the very clear, oligotrophic waters at the Kastelorizo site.

The Pope and Fry (1997) absorption values for pure water and the seawater scattering coefficients of Morel (1974) as retabulated by Smith and Baker (1981), were used in our model simulations. Particle absorption at depth $z$ and wavelength $\lambda, a_{p}(z, \lambda)$, was estimated using the
Morel (1991) model and the chlorophyll-specific absorption coefficients given in Prieur and Sathyendranath (1981). Absorption by $\mathrm{CDOM}, a_{\mathrm{CDOM}}(z, \lambda)$, was assumed to covary with particle absorption according to $a_{\mathrm{CDOM}}(z, \lambda)=0.2 \cdot a_{p}(z, 440) \cdot \exp [-0.014 \cdot(\lambda-440)]$ (Mobley and Sundman, 2000). Particulate scattering was estimated using the Gordon and Morel (1983) model, while CDOM was assumed to be non-scattering. Since measurements of particulate backscattering were not available, a backscattering fraction of 0.044 was used in our calculations based on previous studies for clear waters (e.g. Mobley, 1994; Stramski et al., 2004). Raman scattering and CDOM and chlorophyll-a fluorescence were included in all model runs using the Hydrolight default assumptions for fluorescence efficiency and wavelength redistribution functions for fluorescence by chlorophyll (Mobley, 1994) and CDOM (Hawes, 1992).

Water surface roughness was estimated assuming that the slope probability distribution of the capillary waves follows the Cox and Munk (1954) wind-direction independent distribution. A wind speed of $5 \mathrm{~m} \mathrm{~s}^{-1}$ was used in the simulations based on local meteorological observations. The water column was assumed to be infinitely deep below the greatest depth of interest (ca. $250 \mathrm{~m}$ ). Model results included underwater vertical profiles of photosynthetically active radiation, PAR (in $\mu$ mol phot $\mathrm{m}^{-2} \mathrm{~s}^{-1}$ ), estimated according to Mobley (1994) from underwater scalar irradiance, $E_{o}(z, \lambda)$, and integrated over the spectral region $400-700 \mathrm{~nm}$.

\section{Results and discussion}

3.1 The effect of the solar eclipse on photosynthesis and stomatal conductance

The diurnal course of meteorological parameters during 29 March 2006 is shown in Fig. 1. Solar global irradiance (Fig. 1a) displayed a sharp decline of $796 \mathrm{~W} \mathrm{~m}^{-2}$ during the eclipse, in comparison with the pre-eclipse maximum. A decline was also exhibited in air temperature $\left(2.2^{\circ} \mathrm{C}\right.$, Fig. 1b) and atmospheric pressure $(0.7 \mathrm{hPa}$, Fig. 1d). On the other hand, relative humidity increased by about $10 \%$ (Fig. 1c). More details on the meteorological response of the atmosphere during the March 2006 eclipse is given by Founda et al. (2007). The combination of light "switch off" and increased humidity, together with the decreased temperature during eclipses has been previously shown to have an impact on forest trees (e.g. Steppe et al., 2002). The rate of solar irradiance change during the eclipse has been calculated and compared to the corresponding rates during other frequent illumination changes such as dusk, dawn and clouds. This way eclipse conditions are put into context with more familiar illumination changes. During the eclipse, and excluding periods around first and last contact and near totality, the rate of irradiance change varies between $10-15 \mathrm{Watt} \mathrm{m}^{-2} \mathrm{~min}^{-1}$, 


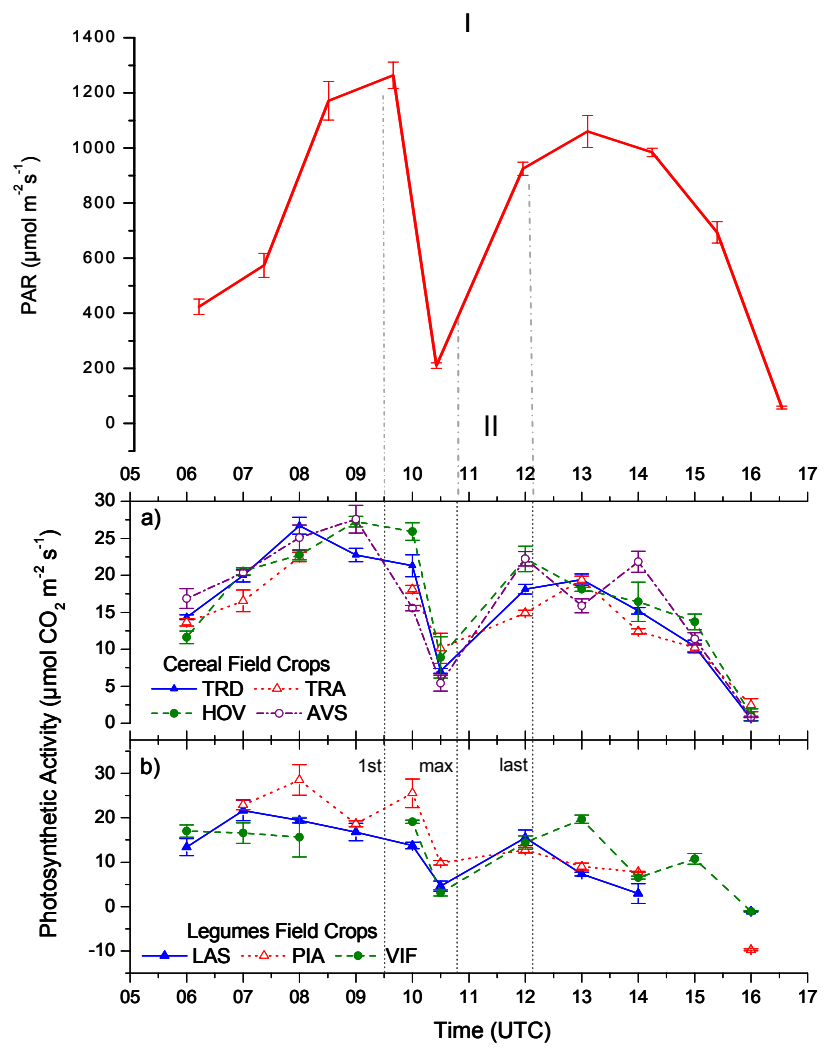

Fig. 2. (I) The course of PAR during the observations at the experimental site. (II) Diurnal changes in $\mathrm{CO}_{2}$ assimilation rate $\left(\mu \mathrm{mol} \mathrm{CO} 2 \mathrm{~m}^{-2} \mathrm{~s}^{-1}\right)$, of four cereals and three leguminous species during 29 March 2006 eclipse, at AUA experimental field (TRD Tr. durum, TRA - Tr. aestivum, HOV - H. vulgare, AVS - A. sativa, LAS - Lathurus sativus, PIA - P. arvense, VIF - V. faba). The bars indicate the standard errors of the means.

within a period of about $2.5 \mathrm{~h}$. The corresponding rates during dusk and dawn were calculated to be in the range 1-3 Watt $\mathrm{m}^{-2} \mathrm{~min}^{-1}$. The situation is more complex for clouds depending on their type and thickness. Calculations on clouds appearing at the site the day after the eclipse, have shown rates of irradiance change varying between 530 Watt $\mathrm{m}^{-2} \mathrm{~min}^{-1}$ with a median of $15 \mathrm{Watt}^{-2} \mathrm{~min}^{-1}$, but these changes are much quicker. Thus, during the eclipse the irradiance change rate appears to be much faster than during dusk and dawn, whereas clouds even though can disturb incoming light at similar rates, is not expected to be as sufficient due to shorter duration and the parallel effect of light scattering by atmospheric particles.

Figure 2I illustrates the course of PAR during the observations at the experimental site. A sharp decline from 1265 at 10:00 UTC to a minimum of $210 \mu \mathrm{mol}$ photons $\mathrm{m}^{-2} \mathrm{~s}^{-1}$ was recorded during the eclipse. High values between 930 and $1060 \mu$ mol photons $\mathrm{m}^{-2} \mathrm{~s}^{-1}$ were recorded shortly after the termination of the phenomenon. Figure 2II shows the diurnal course of photosynthetic rate for the cereals (Fig. 2IIa)
Table 2. Maximum photosynthetic rates observed before the beginning of the eclipse and minimum photosynthetic rates near totality, for the examined species. The minimum/maximum ratios are also shown.

\begin{tabular}{|c|c|c|c|}
\hline \multirow[t]{2}{*}{ Species } & \multicolumn{3}{|c|}{ Photosynthetic rates $\mu \mathrm{mol} \mathrm{CO}_{2} \mathrm{~m}^{-2} \mathrm{~s}^{-1}$} \\
\hline & Max. before & Min. at totality & Min./Max. \\
\hline Triticum durum & 26.70 & 7.08 & 0.2651 \\
\hline Triticum aestivum & 22.47 & 10.13 & 0.4508 \\
\hline Avena sativa & 27.59 & 5.41 & 0.1961 \\
\hline Hordeum vulgare & 27.26 & 8.89 & 0.3261 \\
\hline Lathyrus sativus & 21.66 & 4.61 & 0.2128 \\
\hline Pisum sativum & 28.52 & 9.87 & 0.3461 \\
\hline Vicia faba & 19.12 & 3.13 & 0.1637 \\
\hline
\end{tabular}

and legumes examined (Fig. 2IIb). A drop in photosynthetic rates, by more than a factor of 5 in some cases, was observed as a response to the variation in PAR during the eclipse. The minimum values of observed photosynthetic rates ranged between 3.13 (faba beans) and $10.13 \mu \mathrm{mol} \mathrm{CO}_{2} \mathrm{~m}^{-2} \mathrm{~s}^{-1}$ (bread wheat). The relative reduction of photosynthesis during the eclipse varied among the different species (Table 2, Fig. 2II). Faba beans, oats and grass pea exhibited the more drastic reduction in photosynthesis. On the other end, bread wheat was the least affected species. In general, cereals were less influenced than legumes with average $\mathrm{min} / \mathrm{max}$ ratios 0.31 and 0.24 , respectively.

One-way ANOVA was applied, on three replicates for each species, in order to test the statistical significance of the diurnal fluctuations in stomatal conductance $\left(g_{s}\right)$. Table 3 shows the values of $g_{s}$ for the examined species. In all species except pea, $g_{s}$ showed a decline at 10:00 UTC and at earlier eclipse stages, occasionally significant (e.g., in bread wheat, oats, and faba beans) in comparison with the preceding values. At 10:30 UTC, however, a time near the totality, $g_{s}$ returned to values before the beginning of the eclipse, which were maintained throughout the rest of the day. Thus, the drop in $g_{s}$ at 10:00 UTC is probably not eclipse-induced.

The results of Table 3 imply that the diurnal course of $g_{s}$ in all species followed the typical pattern expected for mesophytes: higher values early in the day (06:00-07:00 UTC), steadily declining within the next two-three hours and remaining stable thereafter. It is also known that morning values of $g_{s}$ are higher than those observed in the afternoon for similar values of PAR (Rochette et al., 1991). A midday temporary decrease in $g_{s}$ is also a common phenomenon in dry environments, like the one of southern Greece. Accordingly, the drop in $g_{s}$ observed at 10:00 UTC may simply reflect normal, "midday stomatal closure" (Miller, 1938; Meidner and Mansfield, 1968).

Stomatal movements are decisively influenced by environmental factors (Meidner and Mansfield, 1968). Light is considered amongst the most important factors determining 
Table 3. Diurnal changes in stomatal conductance as least means (mmol g H $\mathrm{O} \mathrm{m}^{-2} \mathrm{~s}^{-1}$ ), of four cereals and three leguminous species during the 29 March 2006 eclipse, at AUA experimental field. Values followed by the same letter are not statistically significant at the $95 \%$ significance level.

\begin{tabular}{cccccccc}
\hline \multicolumn{7}{c}{ Crop species } \\
\hline Time (UTC) & Bread wheat & Durum wheat & Oats & Barley & Grass pea & Pea & Faba beans \\
\hline $06: 00$ & $1.87 a$ & $1.14 a$ & $0.94 a$ & $0.47 a b$ & $2.10 a$ & $1.58 a$ & $0.90 a$ \\
$07: 00$ & $0.80 b c$ & $0.66 b$ & $0.49 c$ & $0.51 a$ & $1.09 b$ & $1.41 a$ & $0.46 b$ \\
$08: 00$ & $0.40 d$ & $0.50 c$ & $0.64 b$ & $0.50 a b$ & $0.52 c d$ & $0.71 b$ & $0.35 c d$ \\
$09: 00$ & $1.08 b$ & $0.31 d e$ & $0.35 d$ & $0.33 c$ & $0.42 c d$ & $0.22 c$ & $0.30 d e$ \\
$10: 00$ & $0.35 d$ & $0.29 e$ & $0.17 g$ & $0.28 c d$ & $0.27 d$ & $0.41 b c$ & $0.16 f$ \\
$10: 30$ & $0.55 c d$ & $0.38 d e$ & $0.25 e f g$ & $0.33 c$ & $0.36 c d$ & $0.38 c$ & $0.34 c d$ \\
$12: 00$ & $0.41 d$ & $0.42 c d$ & $0.29 d e f$ & $0.43 b$ & $0.62 c$ & $0.30 c$ & 0.22 ef \\
$13: 00$ & $0.30 d$ & $0.43 c d$ & $0.20 f g$ & $0.25 d e$ & $0.32 c d$ & $0.20 c$ & $0.35 c d$ \\
$14: 00$ & $0.24 d$ & $0.33 d e$ & $0.33 d e$ & $0.34 c$ & $0.31 c d$ & $0.25 c$ & 0.24 ef \\
$15: 00$ & $0.22 d$ & $0.30 e$ & $0.36 d$ & $0.49 a b$ & - & - & $0.40 b c$ \\
$16: 00$ & $0.34 d$ & $0.11 f$ & $0.16 g$ & $0.18 e$ & $0.19 d$ & $0.42 b c$ & 0.21 ef \\
\hline
\end{tabular}

Table 4. Diurnal changes in the average intercellular $\mathrm{CO}_{2}$-concentration (ppm) of the crop species examined during the 29 March 2006 eclipse. Values within a species followed by the same letter are not statistically significant at the $95 \%$ significance level.

\begin{tabular}{cccccccc}
\hline \multicolumn{7}{c}{ Crop species } \\
\hline Time (UTC) & Bread wheat & Durum wheat & Oats & Barley & Pea & Grass pea & Faba beans \\
\hline 07:00 & $350.57 a$ & $357.50 a$ & $341.50 a$ & $322.33 c$ & $351.87 c$ & $344.73 b$ & $333.67 b$ \\
$08: 00$ & $324.80 b$ & $298.30 b$ & $301.03 b$ & $300.46 c$ & $359.60 c$ & $317.90 c$ & $296.03 b$ \\
$09: 00$ & $242.80 d$ & $247.30 c$ & $271.80 c$ & $263.60 c d$ & $298.70 d$ & $282.40 d$ & $271.53 b$ \\
$10: 00$ & $254.96 d$ & $215.06 d$ & $207.46 e$ & $212.63 e$ & $208 ., 33 e$ & $267.20 e$ & $300.60 b$ \\
$10: 40$ & $325.36 b$ & $341,00 a$ & $327,33 a$ & $482,50 a$ & $557,56 a$ & $337,23 b$ & $368,76 a$ \\
$12: 00$ & $278.06 c$ & $276.40 c$ & $210.96 e$ & $270.10 c$ & $273.73 d$ & $284.53 d$ & $231.43 c$ \\
$13: 00$ & $226.46 d$ & $254.23 c$ & $209.00 e$ & $208.50 e$ & $288.26 d$ & $295.73 d$ & $230.10 c$ \\
$14: 00$ & $264.23 c$ & $270.93 c$ & $235.86 d$ & $276.40 c$ & $300.53 d$ & $339.93 b$ & $320.03 b$ \\
$15: 00$ & $232.76 d$ & $296.23 b$ & $296.06 b$ & $300.63 c$ & & & $305.30 b$ \\
$16: 00$ & $361.90 a$ & $372.66 a$ & $353.80 a$ & $358.86 b$ & $454.63 b$ & $380.70 a$ & $376.26 a$ \\
\hline
\end{tabular}

the course of stomatal behaviour, although many interactions with other environmental (e.g. $\mathrm{CO}_{2}$-concentration, vapour pressure deficit, temperature, etc.) and plant factors (plant water status, endogenous rhythms) exist to a considerable extent. Accordingly, the lack of a response of $g_{s}$ to the dramatic fall in solar irradiance during the eclipse is surprising and could be attributed to an endogenous buffering reaction against the rapidly falling rate in the incoming radiant energy $\left(0.177 \mathrm{~W} \mathrm{~m}^{-2} \mathrm{~s}^{-1}\right)$. The "normal" diurnal falling rate observed between 14:00 and 16:00 UTC on the same day, which was also associated with a fall in $g_{s}$ for most of the examined species (Table 3$)$, was much smaller $\left(0.065 \mathrm{~W} \mathrm{~m}^{-2} \mathrm{~s}^{-1}\right)$. Judging from the course of the environmental variables during the eclipse (Fig. 1), no dramatic changes in plant water status, to an extent affecting stomatal movements, were likely to occur. In contrast to our findings, a moderate decline in $g_{s}$ was observed in forest trees at total solar eclipse in Central Europe (Häberle et al., 2001).

Mesophyll $\mathrm{CO}_{2}$-concentration $\left(C_{i}\right)$ was significantly raised at totality for all the examined species (Table 4 ). The levels of $C_{i}$ were equivalent (in bread and durum wheat, oats, grass pea, faba beans) or even higher (in barley and pea) than those observed at dawn or dusk. Such an increase in intercellular $\mathrm{CO}_{2}$-evolution is usually observed after darkening leaves of $\mathrm{C}_{3}$ plants photosynthesizing in air and can be attributed both to photorespiration and tricarboxylic acid (TCA) respiration ("post-illumination burst"; Lawlor, 2001). Evidently, these raised levels of $C_{i}$ were not able to induce stomatal closure during the eclipse.

It is clear from the results of $g_{s}$ that the observed fall in net photosynthesis cannot be attributed to stomatal closure and, hence, to a reduced $\mathrm{CO}_{2}$-supply. Therefore, one could expect 
Table 5. Diurnal changes in the average rate of $\mathrm{CO}_{2}$-uptake $(\mathrm{ppm})$ per intercepted photon $\left(\mu \mathrm{mol} \mathrm{m} \mathrm{s}^{-2} \mathrm{~s}^{-1}\right.$ of the crop species examined during the March 29, 2006 eclipse. Values within a species followed by the same letter are not statistically significant at the $95 \%$ significance level.

\begin{tabular}{cccccccc}
\hline \multicolumn{7}{c}{ Crop species } \\
\hline Time (UTC) & Bread wheat & Durum wheat & Oats & Barley & Pea & Grass pea & Faba beans \\
\hline $07: 00$ & $0.0353 a$ & $0.0586 a$ & $0.0460 a$ & $0.0336 b c$ & - & $0.0273 b$ & $0.0303 a$ \\
$08: 00$ & $0.0286 a$ & $0.0273 c$ & $0.0503 a$ & $0.0656 a$ & $0.0256 b$ & $0.0566 a$ & $0.0230 a b$ \\
$09: 00$ & $0.0136 b$ & $0.0187 d$ & $0.0261 c$ & $0.0328 b c$ & $0.0153 c$ & $0.0146 b c$ & $0.0168 b$ \\
$10: 00$ & $0.0148 b$ & $0.0178 d$ & $0.0222 c$ & $0.0228 c$ & $0.0148 c$ & $0.0162 b c$ & $0.0121 b$ \\
$10: 40$ & $0.0345 a$ & $0.0388 b$ & $0.0357 b$ & $0.0408 b$ & $0.0465 a$ & $0.0199 b$ & $0.0182 b$ \\
$12: 00$ & $0.0167 b$ & $0.0219 d$ & $0.0209 c$ & $0.0144 c d$ & $0.0131 c$ & $0.0200 b$ & $0.0146 b$ \\
$13: 00$ & $0.0203 b$ & $0.0196 d$ & $0.0126 e$ & $0.0126 c d$ & $0.0066 c$ & $0.0133 b c$ & $0.0153 b$ \\
$14: 00$ & $0.0110 b c$ & $0.0163 d e$ & $0.0230 c$ & $0.0160 c d$ & $0.0080 c$ & $0.0030 c$ & $0.0046 c$ \\
$15: 00$ & $0.0140 b$ & $0.0110 f$ & $0.0190 c d$ & $0.0200 c d$ & - & - & $0.0210 b$ \\
$16: 00$ & $0.0293 a$ & $0.0070 g$ & $0.0116 e$ & $0.0140 c d$ & $-0.2610 d$ & $-0.5466 d$ & $-0.0303 d$ \\
\hline
\end{tabular}

that the reduced photon flux density would affect mainly the photochemical pathway. Photosynthesis is inherently dependent on light. The three functions of the light harvesting apparatus (light capturing, energy transfer and electron transfer) are controlled by the physical and chemical characteristics of the plant pigments. Absence of light disrupts electron transport, leading to a decline of photosynthesis (Schreiber et al., 1995). An indirect way of checking this hypothesis is to compare the quantum yields $(\Phi)$, i.e. the rate of $\mathrm{CO}_{2}$ uptake per intercepted photon, diurnally over all the examined species (Table 5). A significant increase in $\Phi$ was observed for most species at totality, in comparison to values during the other daylight hours. A marginal, non-significant, increase was exhibited only by faba bean and grass pea. Such an increase in quantum yield observed at totality may imply photoinhibitory effects at bright sunshine for the other crop species (Baker et al., 1994; Ögren, 1994) given that PAR-values at the experimental site were very high already at 09:00 UTC (Fig. 2I).

\subsection{The effect of eclipse on marine zooplankton}

The solar eclipse induced effects on ecosystems has been additionally investigated in the marine environment. These effects are mainly driven by the change of underwater irradiance that has been simulated via the Hydrolight Radiative Transfer Program for the case of Kastelorizo. Figure 3 shows the change with time in downward irradiance as measured above the water surface, $E_{s}$, during the eclipse event. Light intensity dropped dramatically with the onset of the eclipse, with $E_{S}$ at $550 \mathrm{~nm}$ decreasing from $\sim 1.35 \mathrm{~W} \mathrm{~m}^{-2} \mathrm{~nm}^{-1}$ at $09: 35$ UTC (1st contact) to below the range of the instrument's sensitivity during totality 10:53 UTC, increasing again to $\sim 1.16 \mathrm{~W} \mathrm{~m}^{-2} \mathrm{~nm}^{-1}$ at $12: 10 \mathrm{UTC}$ (last contact). Model estimated photosynthetically active radiation (PAR)

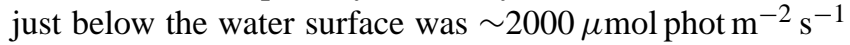

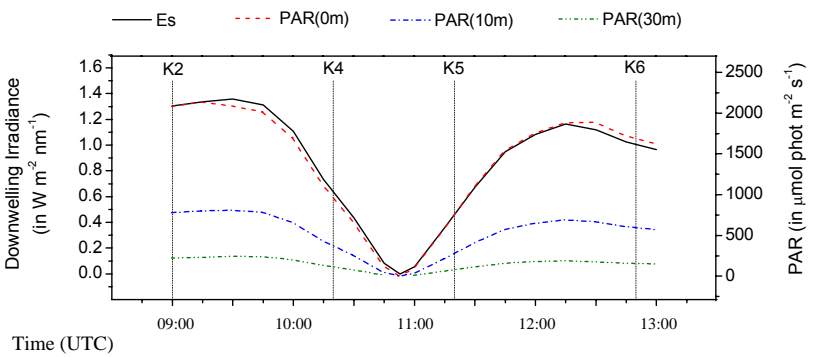

Fig. 3. (Left axis) Change in measured downward surface irradiance (in $\mathrm{W} \mathrm{m}^{-2} \mathrm{~nm}^{-1}$ ) at $550 \mathrm{~nm}$ during the eclipse event (solid line). (Right axis) Change in model estimated photosynthetically active radiation (PAR, in $\mu \mathrm{mol}$ phot $\mathrm{m}^{-2} \mathrm{~s}^{-1}$ ) just below the water surface ( $z=0 \mathrm{~m}$, dash line), at $10 \mathrm{~m}$ depth (dash-dot line), and at $30 \mathrm{~m}$ depth (dash dot dot line). The exact times of the casts K2, K4, K5 and K6 are shown as vertical dash lines.

just before the 1st contact, while the evolution of PAR at more depths $(10$ and $30 \mathrm{~m})$ is also shown in Fig. 3.

The water column structure at the sampling station before, during and after the eclipse is described in Fig. 4. Temperature and salinity ranged from 16.2 to $17^{\circ} \mathrm{C}$ and from 39 to $39.2 \mathrm{psu}$, respectively, in the upper $200 \mathrm{~m}$. Due to spring warming, the surface layer (from the surface down to 20 $30 \mathrm{~m}$ ) is warmer and saltier than the underlying waters, transported in the area by the Asia Minor current (POEM group, 1992). The water mass under the thermocline is the Levantine Intermediate water, with almost homogenous temperature and salinity extended down to $250 \mathrm{~m}$. Temperature and salinity remained almost constant during the eclipse event. Chl-a concentration varied from 0.14 to $0.19 \mu \mathrm{gl}^{-1}$, with a small chlorophyll maximum between 40 and $60 \mathrm{~m}$. No significant changes in chl-a vertical distribution were observed during the eclipse event. 


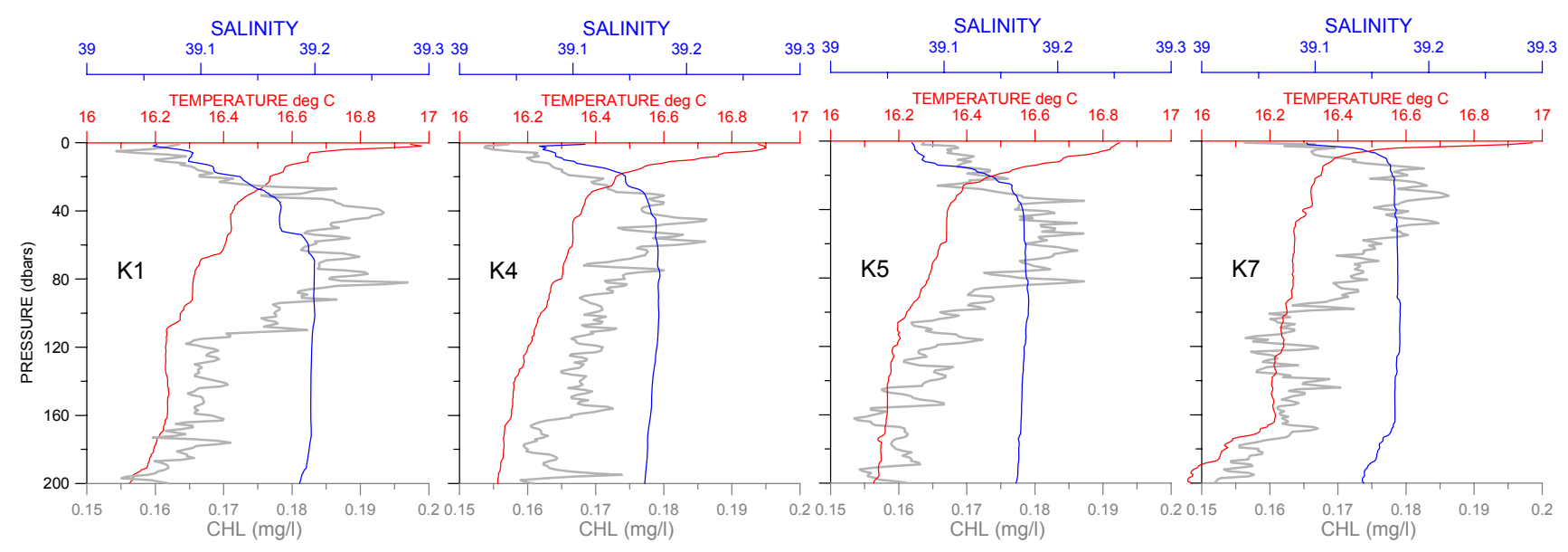

Fig. 4. Distribution of Temperature (red line), Salinity (blue line) and Chlorophyll- $a$ (grey line) versus depth (down to $200 \mathrm{~m}$ ). The profiles $\mathrm{K} 1$ and $\mathrm{K} 7$ represent the water column before the first contact and after the last contact, respectively. The profiles K4 and K5 are taken before and after the maximum of the eclipse.

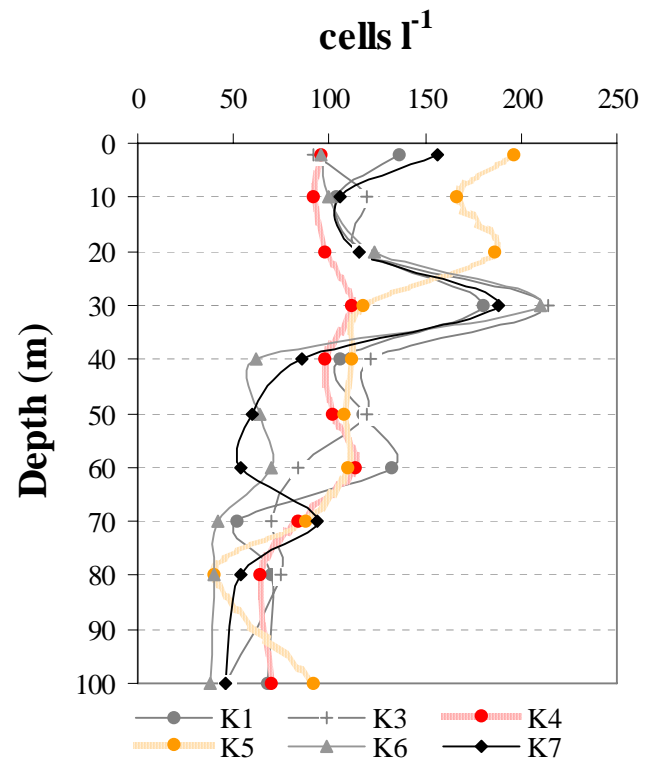

Fig. 5. Vertical distribution (abundance $1^{-1}$ ) of ciliates during different sampling hours. K1 and K7 correspond to the first contact and the last contact respectively. K4 and K5 are taken before and after the maximum of the eclipse.

\subsubsection{Ciliates}

The ciliate community included members of the orders Choreotrichida (Strobilidium spp, Lohmaniella spp), Tintinnida, Oligotrichida (Strombidium spp, Tontonia spp and Laboea spp). Cell numbers were dominated by small oligotrichs $20-30 \mu \mathrm{m}(35-75 \%)$.

From the vertical abundance profiles (Fig. 5, K1 and K3) it was clear that before the eclipse ciliates showed a non-

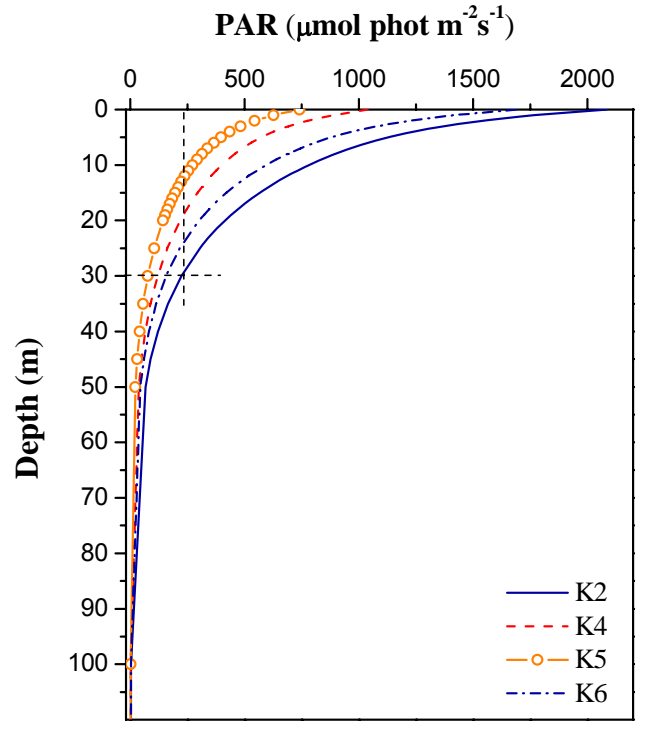

Fig. 6. Vertical profiles of PAR during different sampling hours. The exact time of casts K2, K4, K5 and K6 is shown in Fig. 3.

random distribution and tended to accumulate at $30 \mathrm{~m}$ depth, where they showed a distinct peak in cell numbers (up to 212 cells $1^{-1}$ ). At this depth, PAR was $\sim 11 \%$ of its surface value (cast $\mathrm{K} 2$ in Fig. 6).

However, at 10:20 UTC (cast K4), one hour after the 1st contact and $30 \mathrm{~min}$ before totality, we observed a vertical homogenous spreading of the ciliates in the water column. At this time, surface PAR had already decreased by $\sim 50 \%$. It seemed like ciliates responded to the rapid decrease in light intensity during the eclipse, adopting a night-time behavior. At 11:20 UTC (cast K5), almost $30 \mathrm{~min}$ after totality, when surface PAR was $\sim 35 \%$ of its initial value before 
the eclipse, ciliates were found in greater numbers within the first $20 \mathrm{~m}$ from the surface. Two hours after totality (cast K6 at 12:50 UTC), the notable peak at $30 \mathrm{~m}$ was re-established.

Ciliate diel cycles have been surprisingly little studied before. Jonsson (1989) reported that ciliates often accumulate around the pycnocline, mainly due to the effect of negative geotaxis. Chemokinetic and photokinetic responses have been shown to influence the vertical distributions in some ciliates in lake environments (Finlay et al., 1987). Interactions between sinking velocity, swimming velocity, tumbling rate and shape or density asymmetry of the cell have also been suggested to explain the vertical distribution of planktonic ciliates in natural waters (Jonsson, 1989). Perhaps the ciliate community tried to stay within its optimal photo-environment during the unusually rapid decrease in light intensity due to the eclipse. Vertical migration could also be governed by other factors, such as predation. Ciliates could move downwards in order to avoid predation pressure from zooplankton, accumulated near the surface layers at night. Perez et al. (2000) found in a study at the Western Mediterranean sea, that chlorophyll containing ciliates were mainly concentrated at the chl-a maximum depth, however heterotrophic ciliates often migrated from $20-30 \mathrm{~m}$ depth during the day to the surface at night or in the early morning. Measurements by Stoecker et al. (1989) across Georges Bank (Northwest Atlantic) revealed that oligotrichous ciliates with chloroplasts were usually located in the upper half of the euphotic zone during the day, showing diel changes in their distribution pattern. For example, Laboea strobila was concentrated near the surface just before sunrise and early in the morning, but had a subsurface maximum at noon.

\subsubsection{Mesozooplankton}

The mesozooplankton assemblage was made up $39-74 \%$ by copepods, showing an increasing relative abundance with depth. Copepodites of Clausocalanus, Paracalanus, Oithona and Ctenocalanus dominated the copepod assemblage (up to 40, 42, 19 and 15\% respectively). Less important were Clausocalanus paululus, Ctenocalanus vanus, Oithona plumifera and Oncea media (up to 8-10\%). The non-copepod zooplankton made a significant contribution to the total abundance represented, by 5 taxa: Appendicullaria, Doliolidae, Chaetognatha, Medusae and Pteropoda.

Figure 7 shows the results of copepod vertical distribution at the surface down to $100 \mathrm{~m}$. Copepods exhibited the greatest density between 10-20 m depth. At K4 10:20 UTC when surface PAR was $\sim 50 \%$ (Fig. 6) of that before the eclipse, copepods showed higher abundance close to the surface which can be explained by a possible migrating behaviour. Calanus and Clausocalanus copepodites seemed to be synchronized with the exogenous changes of light due to the eclipse. Individuals of these species showed a vertical migratory movement towards the surface. Among the other copepodites, Paracalanus mainly localized at $0-10 \mathrm{~m}$ in-

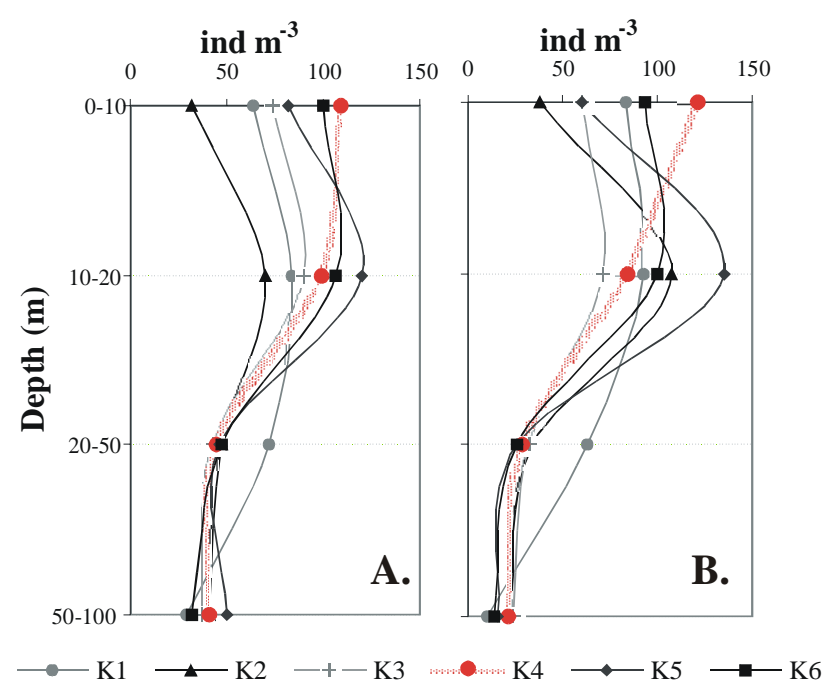

Fig. 7. Vertical distribution (abundance $\mathrm{m}^{-3}$ ) of (a) copepods and (b) other mesozooplankton taxa during different sampling hours. $\mathrm{K} 4$ is taken before the maximum of the eclipse.

creased their abundance in this layer before totality. Oithona plumifera collected mostly in the 10-20 m tows appeared in greater abundance in the $0-10 \mathrm{~m}$ layer, as well as Oncea media concentration increased at the surface layers. The other copepodites, male and female copepods displayed no significant differences in distribution and apparent response to the eclipse.

Similarly, the other zooplankton taxa were distributed high in the water column (10-20 m), whereas the fall of light intensity resulted in a migration upwards to the surface It seems that appendicullaria (Oikopleura dioica), meduses and doliolids responded to light changes and did move up in the water column towards the surface. Pteropods that maintained themselves mainly at $0-10 \mathrm{~m}$ increased their abundance before totality, while chaetognaths did not respond to light changes during the eclipse.

Avoidance of light by zooplankton has been demonstrated by many studies with a remarked preference for the surface layers during dawn and dusk (Conover et al., 1988; Hays et al., 1994). Earlier reports for Pseudocalanus and Calanus species (Runge and Ingram, 1991; Hattori and Saito, 1997), showed that medium to large calanoids exhibited a normal diel vertical migration moving upward into the surface layer sometime between 19:00 and midnight. Calanus is a fast swimmer moving in short bursts of about 15$66 \mathrm{~m} \mathrm{~h}^{-1}$ (Marshall and Orr, 1955). In a study of the diurnal vertical movements of chaetognaths and appendicularia, Schmidt (1973) reported that these animal groups during daytime avoid the upper layers, although around sunset and sunrise they tend to accumulate above $25 \mathrm{~m}$. Consistent with our results are Sherman and Honey (1970) data, reporting that chaetognaths showed little change in vertical distribution 
during the eclipse. However the strong responses reported by Pepita (1955) for chaetognaths and decapod larvae differed from our results, probably due to species composition of the zooplankton.

\section{Summary and conclusions}

The solar eclipse of 29 March 2006 had very important effects on ecosystems, both on plants and marine zoo-plankton, which have been investigated in a parallel field experiment.

The diurnal course of photosynthetic rate for the seven important field-grown cereal and leguminous crops studied here, indicated a dramatic drop during the total phase of the eclipse. The minimum values of observed photosynthetic rates varied among the different species and ranged between 3.13 (faba beans) and $10.13 \mu \mathrm{molCO}_{2} \mathrm{~m}^{-2} \mathrm{~s}^{-1}$ (bread wheat). In general, cereals were less influenced than legumes; in particular, faba beans, oats and grass pea were the most intensely affected species. Thus, they may be used as potential indices for future investigations of shading effects on field crops.

The fluctuations observed in the diurnal cycle of stomatal conductance $\left(g_{s}\right)$ for the examined species could not be attributed to the solar eclipse. Thus, since stomatal closure could not be associated either with solar irradiance or the increased levels of the mesophyll $\mathrm{CO}_{2}$-concentration, effects on the photochemical pathway of photosynthesis may have been responsible for the observed fall in photosynthetic rates. The observations on the quantum yield of photosynthesis before and during eclipse have revealed possible photoinhibitory effects in most species during the hours of bright sunshine. These findings have to be taken under serious consideration for planning solar eclipse related experiments in the future.

The solar eclipse induced effects on the marine environment were mainly driven by the change of underwater irradiance. Model estimated photosynthetically active radiation (PAR) just below the water surface was $\sim 2000 \mu \mathrm{mol}$ phot $\mathrm{m}^{-2} \mathrm{~s}^{-1}$ just before the 1 st contact. Temperature and salinity remained almost constant during the eclipse event. Chl-a concentration varied from 0.14 to $0.19 \mu \mathrm{g} \mathrm{l}^{-1}$. No significant changes in chl-a vertical distribution were observed during the eclipse event.

The behavior of marine populations has been investigated, separately for micro-zooplankton (ciliates) and mesozooplankton. Ciliates, tending to accumulate at $30 \mathrm{~m}$ depth, responded to the rapid decrease in light intensity during the eclipse and adopting night-time behaviour showed a vertical homogenous spreading in the water column. At this time, surface PAR had already decreased by $\sim 50 \%$. From the mesozooplankton assemblage, Calanus and Clausocalanus copepodites having been synchronized with the exogenous changes, showed a vertical migratory movement towards the surface. Among the other copepodites, Paracalanus,
Oithona plumifera as well as Oncea media increased their abundance in the surface layer before totality. The other copepodites, male and female copepods displayed no significant differences in distribution and apparent response to the eclipse. Similarly, the other zooplankton taxa such as appendicullaria (Oikopleura dioica), meduses and doliolids responded to light changes moving up towards the surface.

Overall, given the biodiversity of the Greek territory we seized the opportunity of the March 2006 Total Solar Eclipse to investigate the sensitivity of various species in the biosphere. The different responses ascertained between various species both in field crops and marine zoo-plankton, provide an indication that future climate changes influencing the amount of radiation that reaches the earth's surface, may disturb the stability of the ecosystems, with direct and indirect impacts on crop productivity and in some cases on food chain it self.

Acknowledgements. We would like to thank the crew of the oceanographic R/V AEGAIO for their contribution.

Edited by: C. Zerefos

\section{References}

Backus, R. H., Clark Jun, R. C., and Wing, A. S.: Behaviour of certain marine organisms during the solar eclipse of July 20, 1963, Nature, 205, 989-991, 1965.

Baker, N. R., Farage, P. K., Stirling, C. M., and Long S. P.: Photoinhibition of crop photosyhtesis in the field at low temperatures, in: Photoinhibition of Photosynthesis, edited by: Baker, N. R. and Bowyer, J. R., BIOS Scientific Publishers, London, 349-363, 1994.

Banse, K.: On the vertical distribution of zooplankton in the sea, Prog. Oceanogr., 2, 53-125,1964.

Blumthaler, M., Bais, A., Webb, A., Kazadzis, S., Kift, R., Kouremeti, N., Schallhart, B., and Kazantzidis, A.: Variations of solar radiation at the Earth's surface during the total solar eclipse of 29 March 2006, in: Remote Sensing of Clouds and the Atmosphere XI, edited by: Slusser, J. R., Schäfer, K., and Comeron, A., Proceedings of the SPIE, Vol. 6362, doi:10.1117/12.689630, 2006.

Bright, T., Ferrari, F., and Martin D.: Effects of a total solar eclipse on the vertical distribution of certain oceanic zooplankters, Limnol. Oceanogr., 17(2), 296-301, 1972.

Conover, R. J., Bedo, A. W., Herman, A. W., Head, E. J. H., Harris L. R., and Horne, E. P. W.: Never trust a copepod-some observations on their behaviour in the Canadian Arctic, Bull. Mar. Sci., 43, 650-662, 1988.

Cox, C. and Munk, W.: Statistics of the sea surface derived from sun glitter, J. Mar. Res., 13, 198-227, 1954.

Deen, J. L. and Bruner, M. H.: The effect of the 1932 eclipse upon the width of stomatal openings in gray birch, Ecology, 14, 76-77, 1933.

Fernandez, W., Hidalgo, H., Coronel, G., and Morales, E.: Changes in meteorological variables in Coronel Oviedo, Paraguay, during the total solar eclipse of 3 November 1994, Earth Moon Planets, 74, 49-59, 1996. 
Finlay, B. J., Curds, C. R., Bamforth, S. S., and Bamforth, F. M.: Ciliated protozoa and other micro-organisms from two African lakes, Lake Nakuru and Lake Simbi, Kenya, Arch. Protistenk., 133, 81-91, 1987.

Franceschini, G. A., Bright, T. J., Caruthers, J. W., El-Sayed, S. Z., and Vastano, A. C.: Effects of the total solar eclipse, 7 March (1970) on migration of marine organisms in the Gulf of Mexico, Science, 226, 1155-1156, 1970.

Founda, D., Melas, D., Lykoudis, S., Lisaridis, I., Gerasopoulos, E., Kouvarakis, G., Petrakis, M., and Zerefos, C.: The effect of the total solar eclipse of 29 March 2006 on meteorological variables in Greece, Atmos. Chem. Phys., 7, 5543-5553, 2007, http://www.atmos-chem-phys.net/7/5543/2007/.

Gerasopoulos, E., Andreae, M. O., Zerefos, C. S., Andreae, T. W., Balis, D., Formenti, P., Merlet, P., Amiridis, V., and Papastefanou, C.: Climatological aspects of aerosol optical properties in Northern Greece, Atmos. Chem. Phys., 3, 2025-2041, 2003, http://www.atmos-chem-phys.net/3/2025/2003/.

Gerasopoulos, E., Kouvarakis, G., Vrekoussis, M., Kanakidou, M., and Mihalopoulos, N.: Ozone variability in the marine boundary layer of the Eastern Mediterranean based on 7-year observations, J. Geophys. Res., 110, D15309, doi:10.1029/2005JD005991, 2005.

Gerasopoulos, E., Kouvarakis, G., Vrekoussis, M., Donoussis, C., Kanakidou, M., and Mihalopoulos, N.: Photochemical ozone production in the Eastern Mediterranean, Atmos. Environ., 40, 3057-3069, doi:10.1016/j.atmosenv.2005.12.061, 2006a.

Gerasopoulos, E., Kouvarakis, G., Babasakalis, P., Vrekoussis, M., Putaud, J. P., and Mihalopoulos, N.: Origin and variability of particulate matter (PM10) mass concentrations over the eastern Mediterranean, Atmos. Environ., 40, 4679-4690, doi:10.1016/j.atmosenv.2006.04.020, 2006b.

Gerasopoulos, E., Zerefos, C. S., Tsagouri, I., Founda, D., Amiridis, V., Bais, A. F., Belehaki, A., Christou, N., Economou, G., Kanakidou, M., Karamanos, A., Petrakis, M., and Zanis, P.: The Total Solar Eclipse of March 2006: overview, Atmos. Chem. Phys. Discuss., 7, 17 663-17 704, 2007.

Giroud, C. and Balvay, G.: The solar eclipse and the migration of some planktonic crustacea in Lake Geneva, Arch. Sci., 52, 199 208, 1999.

Gordon, H. R. and Morel, A.: Remote Assessment of Ocean Color for Interpretation of Satellite Visible Imagery, a Review, Lecture Notes on Coastal and Estuarine Studies, Springer Verlag, New York, Vol. 4, 114 pp., 1983.

Häberle, K. H., Reiter, 1., Patzner, K., Heyne, C., and Matyssek, R.: Switching the light off: A break in photosynthesis and sap flow of forest trees under total solar eclipse, Meteorol. Z., 10(3), 201-206, 2001.

Hattori, H. and Saito, H.: Diel changes in vertical distribution and feeding activity of copepods in ice-covered Resolute Passage, Canadian Arctic, in spring 1992, J. Mar. Syst., 11, 205-219, 1997.

Hays, G. C., Proctor, C. A., John, A. W. G., and Warner, A. J.: Interspecific differences in the diel vertical migration of marine copepods: The implication of size, color, and morphology, Limnol. Oceanogr., 39, 1621-1629, 1994.

Hawes, S. K.: Quantum fluorescence efficiencies of marine fulvic and humic acids. Master's Thesis, Dept. of Marine Sc. Univ. of South Florida, St. Petersburg, FL, 1992
Jennings, S., Bustamante, R., Collins, H. K., and Mallinson, J.: Reef fish behaviour during a total solar eclipse at Pinta Island, Galapagos, J. Fish Biol., 53, 683-686, 1998.

Jonsson, P. R.: Vertical distribution of planktonic ciliates - an experimental analysis of swimming behaviour, Mar. Ecol. Prog. Ser., 52, 39-53, 1989.

Kampa, E. M.: Observations of a sonic-scattering layer during the total solar eclipse, 30 June, 1973, Deep Sea Res., 22, 417-423, 1975.

Kazadzis, S., Bais, A., Blumthaler, M., Webb, A., Kouremeti, N., Kift, R., Schallhart, B., and Kazantzidis, A.: Effects of total solar eclipse of 29 March 2006 on surface radiation, Atmos. Chem. Phys., 7, 5775-5783, 2007,

http://www.atmos-chem-phys.net/7/5775/2007/.

Kondratyev, K. Y. and Varotsos, C.: Remote sensing and global tropospheric ozone observed dynamics, Int. J. Remote Sens., 23 (1), 159-178, 2002.

Kourtidis, K., Zerefos, C. S., Rapsomanikis, V., Simeonov, D., Balis, P. E., Perros, A. M., Thompson, J., Witte, B., Calpini, W. M., Sharobiem, A., Papayannis, A., Mihalopoulos, N., and Drakou, R.: Regional levels of ozone in the troposphere over the eastern Mediterranean, J. Geophys. Res., 107(D18), 8140, doi:10.1029/2000JD000140, 2002.

Kouvarakis, G., Vrekousis, M., Mihalopoulos, N., Kourtidis, K., Rappengluck, B., Gerasopoulos, E., and Zerefos, C.,S.: Spatial and temporal variability of tropospheric ozone (O3) in the boundary layer above the Aegean Sea (Eastern Mediterranean), J. Geophys. Res.-Atmos., 107, 8141, doi:10.1029/2000JD000081,2002.

Kumar, A., Phulera, R. P., and Sood, O. P.: Effect of solar eclipse on germination of Dahlbergia sissco and Toona ciliata seed, Indian Forester, 110, 1184-1191, 1984.

Küppers, M., Giersch, C., Schneider, H., and Kirschbaum, M. U. F.: Leaf gas exchange in light- and sun-fecks: response patterns and simulations, in: Trees contributions to modern tree physiology, edited by: Rennenberg, H., Eschrich, W., and Ziegler, H., Backhuys Publishers, Leiden, The Netherlands, 77-96, 1997.

Ladefoged, K.: Transpiration of forest trees in closed stands, Physiol. Plant, 16, 378-414, 1963.

Lawlor, D. W.: Photosynthesis, BIOS Scientific Publishers, Oxford, 386 pp., 2001.

Leuning, R. and Sands, P.: Theory and practice of a portable photosynthesis instrument, Plant Cell Env., 12, 669-678, 1989.

Marshall, S. M. and Orr, A. P.: The biology of a marine copepod, Calanus finmarchicus (Gunnerus), Edinburgh and London, Oliver \& Boyd, 188 pp., 1955.

Longhurst, A. R.: Vertical migration, in: Ecology of the seas, edited by: Cushing, D. H. and Walsh, J. J., Philadelphia, Saunders, W. B. CO, 116-137, 1976.

Meidner, H. and Mansfield, T. A.: Physiology of Stomata. McGRAW- HILL Publishing Company Limited, MaidenhedBerkshire, England, 179 pp., 1968.

Miller, E. C.: Plant Physiology, Mc. Graw-Hill Book Company, Inc., New York and London, 1938.

Mobley, C. D.: A numerical model for the computation of radiance distribution in natural waters with wind-roughened surfaces, part II; user's guide and code listing. NOAA Tech. Memo ERL PMEL-81 (NTIS PB88-246871) (Pacific Marine Environmental Laboratory, Seattle, Wash.), 1988. 
Mobley, C. D.: Light and Water: Radiative Transfer in Natural Waters, Academic Press, San Diego, CA, 1994.

Mobley, C. D. and Sundman, L. K.: Hydrolight 4.1-Users Guide (Sequoia Scientific, Inc., 2000.

Morecroft, M., Oliver, H., Stokes, V., and Morison, J.: Sensing and mis-sensing the eclipse, Weather, 55, 174-176, 2000

Morel, A.: Optical Properties of pure water and pure seawater, in: Optical Aspects of Oceanography, edited by: Jerlov, N. G. and Steeman, E., Academic, London, 1-24, 1974.

Morel, A.: Light and marine photosynthesis: a spectral model with geochemical and climatological implications, Prog. Oceanog., 26, 263-306, 1991.

Ögren, E.: The significance of photoinhibition for photosynthetic productivity, in: Photoinhibition of Photosynthesis, edited by: Baker, N. R. and Bowyer, J. R., BIOS Scientific Publishers, London, 433-447, 1994.

Papayannis, A., Balis, D., Bais, A. F., Van der Bergh, H., Calpini, B., Durieux, E., Fioranni, L., Jaquet, L., Ziomas, I. C., and Zerefos, C. S.: Role of Urban and Suburban Aerosols on Solar UV Radiation Over Athens, Greece, Atmos. Environ., 32, 12, 2193 2201, 1998.

Pepita, T. S.: Observations on the behaviour of zooplankton during a solar eclipse, Dokl. Akad. Nauk. SSSR, 104, 323-325, 1955 (in Russian).

Perez, M. T., Dolan, J. R., Vidussi, F., and Fukai, E.: Diel vertical distribution of planktonic ciliates within the surface layer of the NW Mediterranean (May 1995), Deep Sea Res. I, 47(3), 479503, 2000.

POEM group.: General circulation of the Eastern Mediterranean, Earth Sci. Rev., 32, 285-309, 1992.

Pope, R. M. and Fry, E. S.: Absorption spectrum (380-700 nm) of pure water. II. Integrating measurements, Appl. Optics, 36, 8710-8723, 1997.

Prieur, L. and Sathyendranath, S.: An optical classification of coastal and oceanic waters based on the specific spectral absorption curves of phytoplankton pigments, dissolved organic matter, and other particulate materials, Limnol. Oceanogr., 26(4), 671689, 1981.

Ringelberg, J.: Changes in light intensity and diel vertical migration: a comparison of marine and freshwater environments, Mar. Biol Assoc. UK, 75, 15-25, 1995.

Rochette, P., Pattey, E., Desjardins, R. L., Dwyer, L. M., Stewart, D. W., and Dubé, P. A.: Estimation of maize (Zea mays L.) canopy conductance by scaling up leaf stomatal conductance, Agr. Forest Meteorol., 54(2-4), 241-261, 1991.

Runge, J. A. and Ingram, R. G.: Under ice feeding and diel migration by the planktonic copepods Calanus glacialis and Pseudocalanus minutus in relation to the ice algal production cycle in Southeastern Hudson Bay, Canada, Mar. Biol., 108(2), 217-225, 1991.

Sathaiah, V., Reddy, T. P., and Vaidyanath, K.: Cytological effects of solar eclipse in root meristems of plant systems, Cytologia, 49, 815-822, 1984.
Schreiber, U., Bilger, W., and Neubauer, C.: Chlorophyll fuorescence as a nonintrusive indicator for rapid assessment of in vitro photosynthesis, in: Ecophysiology of photosynthesis, edited by: Schulze, E. and Caldwell D. M.-M., Springer, Berlin, 49-70, 1995

Schmidt, H. E.: The vertical distribution and diurnal migration of some zooplankton in the Bay of Eilat (Red Sea), Helgolander wiss, Meeresunters., 24, 333-340, 1973.

Schulze, E. D. and Hall, A. E.: Stomatal responses, water loss, and nutrient relations in contrasting environments, in: Encyclopedia of plant ecology 12B, physiological plant ecology II, edited by: Lange O. L., Nobel, P. S., Osmond, C. B., and Ziegler, H., Springer, Berlin, 182-230, 1982.

Sherman, K. and Honey, K. A.: Vertical movements of zooplankton during a solar eclipse, Nature, 227(5263), 1156-1158, 1970.

Singh, D. P., Kumar, A., Singh, P., Singh, V. P., Sheoran, I. S, and Singh, M.: Effect of solar eclipse on atmospheric environment, photosynthesis, evapotranspiration and water use efficiency of chickpea (Cicer arietinum L.) and wheat (Triticum aestivum L.), Crop Res., 5, 209-214, 1992.

Skud, B. E.: Responses of marine organisms during the solar eclipse of July 1963, Fish. B.-NOAA, United States National Marine Fisheries Service, 66(2), 259-271, 1967.

Smith, R. C. and Baker, K. S.: Optical properties of the clearest natural waters (200-800 nm), Appl. Optics, 20, 177-184, 1981.

Steppe, K., Lemeur, R., and Samson, R.: Sap flow dynamics of a beech tree during the solar eclipse of 11 August 1999, Agr. Forest Meteorol., 112(3-4), 139-149, 2002

Stoecker, D. K., Taniguchi, A., and Michaels, A. E.: Abundance of autotrophic, mixotrophic and heterotrophic planktonic ciliates in shelf and slope waters, Mar. Ecol. Prog. Ser., 50, 241-254, 1989.

Stramski, D., Boss, E., Bogucki, D., and Voss, K. J.: The role of seawater constituents in light backscattering in the ocean, Prog. Oceanogr., 61(1), 27-55, 2004.

Tont, S. A. and Wick, G. L.: Response of a deep scattering layer to 1972 total solar eclipse, Deep Sea Res., 20(8), 769-771, 1973.

Tramer, E. J.: Bird behavior during a total solar eclipse, Wilson Bull., 112, 432-432, 2000.

Tzortziou, M., Herman, J., Gallegos, C., Neale, P., Subramaniam, A., Harding, L., and Ahmad, Z.: Bio-Optics of the Chesapeake Bay from Measurements and Radiative Transfer Closure, Estuar. Coast. Shelf S., 68, 348-362, 2006.

Utermohl, H.: Zur vervollkommnung der quantitativen phytoplankton methodik. Mitt. Int. Ver. fur Theor., Anderwandte Limnol., 9, 1-38, 1958.

Varotsos, C., Alexandris, D., Chronopoulos, G., and Tzanis, C.: Aircraft observations of the solar ultraviolet irradiance throughout the troposphere, J. Geophys. Res.-Atmos., 106(D14), 14 843-14 854, 2001.

Vecchione, M., Maples, R. S., and Donahoe, R.: Changes in chlorophyll a concentrations in a shallow water column during a solar eclipse, Contrib. Mar. Sci., 29, 37-44, 1987.

Zerefos, C., Meleti, C., Balis, D., Tourpali, K., and Bais, A. F.: Quasi-biennial and longer-term changes in clear sky UV-B solar irradiance, Geophys. Res. Lett., 25, 23, 4345-4348, 1998.

Zirker, J. B.: Total Eclipses of the Sun, Princeton University Press, Princeton, 228 pp., 1995. 